\title{
Assessment of Sexual Functions in Male Patients with Ankylosing Spondylitis Compared with Healthy Controls
}

\author{
Erkek Ankilozan Spondilit Hastalarında Seksüel Fonksiyonların Değerlendirilmesi ve \\ Sağlıklı Kontrollerle Karşılaştırılması
}

\author{
Aylin REZVANİ, ${ }^{1}$ Şeniz ÖK, ${ }^{2}$ Saliha Eroğlu DEMİR ${ }^{1}$ \\ ${ }^{1}$ Department of Physical Medicine and Rehabilitation, Bezmialem Vakıf University, İstanbul, Turkey; \\ ${ }^{2}$ Department of Physical Medicine and Rehabilitation, Gebze Fatih Hospital, Izmit, Turkey
}

\begin{abstract}
Objectives: This study aims to investigate the impact of ankylosing spondylitis (AS) on sexual functions in male patients, to compare the results with healthy male controls, and to identify the associations with disease-related variables.
\end{abstract}

Patients and methods: A total of 39 male patients with AS (mean age 38 years; range 27 to 52 years) and 27 healthy male subjects (mean age 30 years; range 23 to 45 years) were included in the study. The Bath Ankylosing Spondylitis Metrology Index (BASMI), the Bath Ankylosing Spondylitis Functional Index (BASFI), the Bath Ankylosing Spondylitis Disease Activity Index (BASDAI), the Short Form 36 (SF-36) and the Ankylosing Spondylitis Quality of Life (ASQoL) questionnaire were used for those with AS, while the International Index of Erectile Function (IIEF) and the Beck Depression Inventory (BDI) were utilized for all the study subjects.

Results: The frequency of erectile dysfunction in the male patients with AS and the healthy controls was $43.6 \%$ and $51.9 \%$, respectively. No statistically significant differences were found with regard to demographic characteristics, the IIEF, or the BDI scores between the two groups $(p>0.05)$. No significant correlation was found between any domain of the IIEF and the AS indices or laboratory parameters. However, erectile function, overall satisfaction, the total IIEF, and the level of erectile dysfunction were found to be correlated with the BDI.

Conclusion: Sexual dysfunction is common in male patients with AS; however, we could not find any statistically significant differences between them and the healthy male controls in terms of sexual functions. Sexual dysfunction in male patients with AS seems to be associated with an unfavorable psychological status.

Key words: Ankylosing spondylitis; depression; male; quality of life; sexuality.
Amaç: Bu çalışmada, ankilozan spondilitin (AS), erkek hastalarda seksüel fonksiyon üzerindeki etkisi, araştırıldı, sonuçlar sağlıklı erkek kontrollerle karşılaştırıldı ve hastalık ile ilgili değişkenlerle olan ilişkisi belirlendi.

Hastalar ve yöntemler: Çalışmaya toplam 39 erkek AS hastası (ort. yaş 38 yıl; dağılım 27-52 yıl) ve 27 sağlıklı erkek birey (ort. yaş 30 yıl; dağılım 23-45 yıl) dahil edildi. Bu çalışmadaki AS hastalarına Bath Ankilozan Spondilit Metroloji Indeksi (BASMI), Bath Ankilozan Spondilit Fonksiyonel İndeksi (BASFI), Bath Ankilozan Spondilit Hastalık Aktivite Indeksi (BASDAI), Kısa Form 36 (SF-36) ve Ankilozan Spondilit Yaşam Kalitesi (ASQoL) anketi uygulanırken, tüm bireylere Uluslararası Erektil Fonksiyon Indeksi (IIEF) ve Beck Depresyon Envanteri (BDI) uygulandı.

Bulgular: Erektil disfonksiyon sıklığı, erkek AS hastalarında ve sağlıklı erkek kontrollerde sırasıyla \%43.6 ve \%51.9 idi. İki grup arasında demografik özellikler açısından, IIEF ve BDI skorları bağlamında istatistiksel anlamlı farklılıklar tespit edilmedi $(p>0.05)$. Uluslararası Erektil Fonksiyon İndeksinin hiçbir ilgi alanı ile AS indeksleri ve laboratuvar parametreleri arasında anlamlı ilişki bulunmadı. Ancak erektil fonksiyon, total memnuniyet, total IIEF ve erektil disfonksiyon seviyesi ile BDI arasında ilişki saptandı.

Sonuç: Erkek AS hastalarında seksüel disfonksiyon sık gözlenmektedir; ancak bu çalışmada erkek AS hastaları ve sağlıklı erkek kontroller arasında seksüel fonksiyonlar açısından istatistiksel olarak anlamlı farlılık saptanmadı. Erkek AS hastalarında seksüel disfonksiyonun kötü psikolojik durum ile ilişkili olduğu düşünülebilir.

Anahtar sözcükler: Ankilozan spondilit; depresyon; erkek; yaşam kalitesi; cinsellik. 
In males, erectile dysfunction (ED) is a sexual dysfunction characterized by the inability to develop or maintain an erection of the penis sufficient for satisfactory sexual performance. ${ }^{[1]}$ It is known to have a negative impact on health, quality of life (QoL), and partnership. ${ }^{[2]}$ The factors that are involved in the progress of sexual function consist of physiological, psychological, sociocultural, and sexual self-perception, any of which can limit the sexual functioning of an individual. ${ }^{[3]}$

Chronic diseases are risk factors for ED, and they frequently affect sexual functions. Recently, sexuality and its related problems, which are often neglected by physicians or other health professionals, have been investigated in conjunction with different rheumatic diseases. There were multiple factors that negatively impact sexual functions in both men and women with rheumatic diseases. For instance, pain, fatigue, stiffness, functional impairment, depression, anxiety, negative body image, reduced libido, hormonal imbalance, and drug treatment were identified. ${ }^{[4]}$

Ankylosing spondylitis (AS) is a chronic, inflammatory, systemic rheumatic disease that primarily affects the axial skeleton, peripheral joints, paravertebral soft tissues, and entheses. ${ }^{[5]}$ It mostly affects men, especially in their sexually active ages. Some studies have suggested that progression in AS is most rapid in the first 10 years of the disease, ${ }^{[6,7]}$ and this fact can greatly influence sexual activity. Otherwise, sexual problems created by both physical changes of the illness and its attendant distress not only affect these patients, but also their partners. ${ }^{[8]}$

In recent times, there has been a striking increase in the number of studies about the impact of AS on sexual functions in which patients were evaluated using different methods than had previously been undertaken. It was proposed that sexual function is best assessed via a patient self-reported technique. ${ }^{[9]}$ However, some of the previous studies used a mixed, non-standard survey that included different questions about the impact of AS on sexual relationships and did not use validated questionnaires. ${ }^{[3,10,11]}$ Only a few studies exist that have utilized validated questionnaires. ${ }^{[9,12-14]}$ However, each of these studies used a different validated scale, and the differences in their methods led to the controversial results. Therefore, further studies are necessary to clarify this issue.

Using the International Index of Erectile Function (IIEF) scoring system, the primary aim of the present study was to assess sexual functions in male patients with AS and compare the results with a healthy control group. A secondary aim was to determine the influence of demographic and disease-related variables and the level of depression on sexual functions in these patients and to compare our results with recently published studies.

\section{PATIENTS AND METHODS}

A total of 39 male patients with AS (mean age 38 years; range 27 to 52 years) and 27 healthy male subjects (mean age 30 years; range 23 to 45 years) participated in this cross-sectional study. All of the AS patients were under regular follow-up care and were recruited from the Rheumatology Outpatient Clinic of a tertiary care center. All of them had fulfilled the Modified New York Criteria for the diagnosis of AS. ${ }^{[15]}$ Participants were questioned about their sexual lives and medical history, including queries about systemic diseases and chronic use of drugs. Patients were eligible to participate to the program if they were above 18 years of age, had been sexually active in the previous four weeks, and were able to understand the content of the questionnaires. Exclusion criteria included the inability of the patient to reliably respond to the questionnaires, comorbidities that affected internal organs, patients under medications such as antidepressants, those with mental retardation or severe arthritis, and those using a prosthetic device. Healthy controls, either employees working in the authors' hospitals or family members who accompanied patients to these hospitals, were recruited from the Physical Medicine and Rehabilitation and the Rheumatology Outpatient Clinics of two hospitals. A self-assessment questionnaire was prepared to provide privacy and personal secrecy for the healthy subjects, who had been questioned ahead of time to determine their eligibility for participation in the study. If they were eligible, the questionnaire was given to the subjects, and the content of the questionnaire was explained. According to their wishes, the use of a nickname was permitted. All individuals gave their informed consent, and our local ethics committee approved the study. The required sample size was calculated using a general power analysis program, G*power, (Erdfelder, Faul, \& Buchner, 1996). The criterion for significance $(\alpha)$ was set at 0.05 . A priori power analysis suggested that a sample size of 64 (32 subjects per group) was required based on a large effect size (0.71), and the power was set at 0.80 to yield a statistically significant result. 


\section{Main outcome measures}

All subjects were questioned about their demographic characteristics [age, gender, body mass index (BMI) $\left.\left(\mathrm{kg} / \mathrm{m}^{2}\right)\right]$. The duration of symptoms and the duration since diagnosis were also obtained, and the presence of peripheral arthritis, erythrocyte sedimentation rate (ESR) and C-reactive protein (CRP) levels were recorded. The degree of pain at night, the average amount of total pain due to AS in the last week, the patient's global assessment, and the physician's global assessment were evaluated with a 0-100 mm unremarkable visual analog scale (VAS) $(0=$ no pain; $100=$ severe pain). Spinal mobility was assessed by the measurement of the tragus-wall distance (TWD), a modified Schober's test, lateral spinal flexion, intermalleolar distance, and cervical rotation to evaluate the present status and progression of the disease with the Bath Ankylosing Spondylitis Metrology Index (BASMI) ${ }^{[16]}$ Four patients reported that outcome instruments like the Bath Ankylosing Spondylitis Functional Index (BASFI), ${ }^{[17,18]}$ the Bath Ankylosing Spondylitis Disease Activity Index (BASDAI). ${ }^{[19,20]}$ Short Form 36 (SF-36). ${ }^{[21]}$ and AS Quality of Life Questionnaire (ASQoL) $]^{[22]}$ had been used to assess functional status, disease activity, generic QoL and disease-specific QoL. The SF-36 is used to evaluate eight dimensions of physical and mental health within the previous four weeks, including physical functioning, the physical role, bodily pain, general health, vitality, social functioning, the emotional role, and mental health. Each domain was scored on a scale from 0 to 100 , with higher scores indicating good QoL. ${ }^{[21]}$ The ASQoL is comprised of 18 items, and each item is scored as a " 1 " or " 0 ". A score of "1" indicates poor QoL. The total scores range from 0 to 18 , with a higher score indicating a poor QoL. ${ }^{[22]}$

The validated Turkish version of the IIEF, a 15 -item questionnaire that is a valuable tool for defining the area of sexual dysfunction, is designed to be a selfadministered measure of erectile dysfunction. It was used in this study to investigate sexual dysfunction in both the male patients with AS and the healthy male subjects taking part in the study. It consists of five domains of erectile function: six questions about erectile function, two about orgasmic function, two about sexual drive, three about intercourse satisfaction, and two about overall satisfaction. The scoring of the IIEF allows for patients to be classified as either having no (26-30), mild (17-25), moderate (11-16) or severe (0-10) ED. ${ }^{[23,24]}$
The Beck Depression Inventory (BDI), a reliable and valid instrument for measuring depression symptom severity, was used to investigate the patients' affective state. It is a self-reported questionnaire composed of 21 items presented in multiple-choice format that aims to measure the presence and degree of depression with scores ranging from 0 to 63 , with higher scores representing more severe symptoms. Responses are recorded on a four-point scale and range from 0 to 3 , with a " 3 " representing the most severe symptoms. There are no cutoff points on the BDI to specifically classify depression and its different severities. However, a score of greater than 13 has often been accepted as the cutoff in other studies. ${ }^{[9,25]}$

\section{Statistical analysis}

Statistical analysis was performed with the SPSS (SPSS, Inc., Chicago, Illinois, USA) for Windows version 16.0 statistical software program. Descriptive data was presented as median (minimum-maximum). Demographic characteristics were compared using a chi-square test, and the Mann-Whitney $U$ test was used for comparisons between the two groups. Correlations between sexual dysfunction, sexual status, pain, laboratory parameters, QoL, and AS indices were investigated by Pearson's correlation test for normally distributed variables and by Spearman's rank correlation test for non-normally distributed variables. A p value of less than 0.05 was considered to be statistically significant.

\section{RESULTS}

The body mass index (BMI) was 27.94 ( $m$ in 17.09$\max 39.04)$ for the AS patients and 25.40 ( $\min 20.80$ $\max 31.40$ ) for the healthy controls. No statistically significant differences were found between the two groups in terms of age and BMI $(p=0.129$ and $\mathrm{p}=0.295$, respectively). The clinical characteristics of the male patients with AS and the healthy controls are shown in Table 1, and the AS indices and QoL scores of the AS patients are shown in Table 2. Active disease (BASDAI >4) was found in nine of these patients (23.1\%).

The demographic characteristics along with the IIEF and BDI scores of both groups are shown in Table 3. The frequency of ED in the male patients with AS and the healthy controls was $43.6 \%$ and $51.9 \%$, respectively $(\mathrm{p}=0.512)$. No statistically significant differences were found between the two groups regarding the demographic characteristics, IIEF, or BDI scores ( $p>0.05$ ). 
Table 1. Clinical characteristics of the patients with ankylosing spondylitis

\begin{tabular}{lcc}
\hline & \multicolumn{2}{c}{$\begin{array}{c}\text { Male patients with } \\
\text { AS (n=39) }\end{array}$} \\
\cline { 2 - 3 } & Median & Min.-Max. \\
\hline Duration of symptoms (months) & 120 & $23-312$ \\
Duration since diagnosis (months) & 53 & $0-232$ \\
ESR (mm/h) & 12 & $2-51$ \\
C-reactive protein level (mg/dl) & 0.7 & $0.01-6$ \\
Pain total & 9 & $0-78$ \\
Pain at night & 11 & $0-95$ \\
Patient's global assessment & 10 & $0-95$ \\
Physician's global assessment & 0 & $0-67$ \\
Tragus-wall distance & 15.25 & $6-32.75$ \\
Intermalleolar distance & 92 & $33-132$ \\
Modified Schober's test & 4.5 & $1.5-9.5$ \\
Lateral spinal flexion & 14 & $0.75-22.25$ \\
AS: Ankylosing spondylitis; Min.: & Minimum; & Max.: Maximum; ESR: \\
Erythrocyte sedimentation rate. & \multicolumn{2}{|c|}{} \\
\hline
\end{tabular}

All of the subjects completed the BDI. When a score of greater than 13 was used as the cut-off value for a depressive mood, 10 of the male patients with AS (25.6\%) and six of the healthy controls $(22.2 \%)$ were categorized as being depressed ( $\mathrm{p}=0.493)$.

The relationships between the IIEF and the BDI, pain, AS indices, laboratory parameters, and QoL indices in the male patients with AS were also evaluated (Tables 4 and 5), and we could not find any significant correlation between any domain of the IIEF and the AS indices, including the BASFI, BASDAI and BASMI, and the laboratory parameters $(\mathrm{p}>0.05)$. Erectile function, overall satisfaction, the total IIEF, and the level of ED were found to be negatively correlated with the BDI. Orgasmic function was correlated with the social function subscale of the SF-36, and intercourse satisfaction was correlated with the pain subscale
Table 2. Ankylosing spondylitis indices and quality of life in patients with ankylosing spondylitis

\begin{tabular}{lcc}
\hline & $\begin{array}{c}\text { Male patients with } \\
\text { AS (n=39) }\end{array}$ \\
\cline { 2 - 3 } & \multicolumn{2}{c}{$\begin{array}{c}\text { Median } \\
\text { Min.-Max. }\end{array}$} \\
\hline BASFI & 0.64 & $0-8.63$ \\
BASDAI & 1.5 & $0-8.60$ \\
BASMI & 2 & $1-7$ \\
ASQoL & 2 & $0-17$ \\
Short Form 36 & & \\
Physical function & 85 & $10-100$ \\
Role emotional & 67 & $0-100$ \\
Pain & 82 & $10-100$ \\
General health & 62 & $20-97$ \\
Vitality & 70 & $25-100$ \\
Social function & 88 & $0-100$ \\
Role physical & 75 & $0-100$ \\
Mental health & 64 & $0-80$ \\
\hline AS: Ankylosing spondylitis; Min.: Minimum; Max.: Maximum; BASFI: \\
The Bath Ankylosing Spondylitis Functional Index; BASDAI: The Bath \\
Ankylosing Spondylitis Disease Activity Index; BASMI: The Bath Ankylosing \\
Spondylitis Metrology Index; ASQoL: Ankylosing Spondylitis Quality of Life \\
Questionnaire.
\end{tabular}

on the same instrument. Overall satisfaction was correlated with the ASQoL.

\section{DISCUSSION}

In the current study, the frequency of ED was found to be $43.6 \%$ in the male patients with AS and $51.9 \%$ in the healthy male controls. Contrary to expectations, the prevalence of ED was higher in the healthy controls than in the AS group, and nearly all of the five domains of the IIEF scores were, interestingly enough, higher in the male patients with AS. However, there was no significant difference between the two groups in terms of any of the domains of the IIEF and the prevalence of ED.

\begin{tabular}{|c|c|c|c|c|c|}
\hline \multirow[t]{2}{*}{ Male patients } & \multicolumn{2}{|c|}{ Male patients with AS $(n=39)$} & \multicolumn{2}{|c|}{ Healthy controls $(n=27)$} & \multirow[b]{2}{*}{$p$} \\
\hline & Median & Min.-Max. & Median & Min.-Max. & \\
\hline Total IIEF & 67 & $13-75$ & 63 & $9-73$ & 0.203 \\
\hline Erectile function & 27 & $5-30$ & 26 & $3-30$ & 0.163 \\
\hline Orgasmic function & 9 & $1-10$ & 9 & $0-10$ & 0.611 \\
\hline Sexual drive & 8 & $4-10$ & 8 & $3-10$ & 0.995 \\
\hline Intercourse satisfaction & 12 & $0-15$ & 11 & $0-15$ & 0.090 \\
\hline Overall satisfaction & 9 & $3-10$ & 8 & $2-10$ & 0.334 \\
\hline Level of erectile dysfunction & \multicolumn{2}{|c|}{$22-13-3-1$} & \multicolumn{2}{|c|}{$13-6-6-2$} & 0.230 \\
\hline Beck Depression Inventory & 8 & $0-30$ & 7 & $0-29$ & 0.437 \\
\hline
\end{tabular}


Table 4. The relationship between clinical and laboratory parameters, the International Index of Erectile Function, and the Beck Depression Inventory scores in the male patients with ankylosing spondylitis

\begin{tabular}{|c|c|c|c|c|c|c|c|}
\hline & $\begin{array}{c}\text { Erectile } \\
\text { function }\end{array}$ & $\begin{array}{l}\text { Orgasmic } \\
\text { function }\end{array}$ & $\begin{array}{l}\text { Sexual } \\
\text { drive }\end{array}$ & $\begin{array}{l}\text { Intercourse } \\
\text { satisfaction }\end{array}$ & $\begin{array}{c}\text { Overall } \\
\text { satisfaction }\end{array}$ & $\begin{array}{l}\text { Total } \\
\text { IIEF }\end{array}$ & $\begin{array}{c}\text { Level of } \\
\text { ED }\end{array}$ \\
\hline Total pain & $\begin{array}{l}\mathrm{r}: 0.091 \\
\mathrm{p}: 0.582\end{array}$ & $\begin{array}{l}\mathrm{r}: 0.012 \\
\mathrm{p}: 0.945\end{array}$ & $\begin{array}{l}\mathrm{r}: 0.178 \\
\mathrm{p}: 0.278\end{array}$ & $\begin{array}{l}\mathrm{r}: 0.268 \\
\mathrm{p}: 0.100\end{array}$ & $\begin{array}{l}\mathrm{r}:-0.015 \\
\mathrm{p}: 0.929\end{array}$ & $\begin{array}{l}\mathrm{r}: 0.114 \\
\mathrm{p}: 0.489\end{array}$ & $\begin{array}{l}\mathrm{r}:-0.178 \\
\mathrm{p}: 0.277\end{array}$ \\
\hline Erythrocyte sedimentation rate & $\begin{array}{l}\mathrm{r}:-0.180 \\
\mathrm{p}: 0.272\end{array}$ & $\begin{array}{l}\mathrm{r}:-0.070 \\
\mathrm{p}: 0.670\end{array}$ & $\begin{array}{l}\mathrm{r}: 0.050 \\
\mathrm{p}: 0.764\end{array}$ & $\begin{array}{l}\mathrm{r}: 0.093 \\
\mathrm{p}: 0.575\end{array}$ & $\begin{array}{c}\mathrm{r}:-0.043 \\
\mathrm{p}: 0.797\end{array}$ & $\begin{array}{l}\mathrm{r}:-0.069 \\
\mathrm{p}: 0.675\end{array}$ & $\begin{array}{l}\mathrm{r}: 0.265 \\
\mathrm{p}: 0.103\end{array}$ \\
\hline C-reactive protein level & $\begin{array}{l}\mathrm{r}: 0.116 \\
\mathrm{p}: 0.481\end{array}$ & $\begin{array}{l}\mathrm{r}: 0.265 \\
\mathrm{p}: 0.103\end{array}$ & $\begin{array}{l}\mathrm{r}: 0.212 \\
\mathrm{p}: 0.195\end{array}$ & $\begin{array}{l}\mathrm{r}: 0.221 \\
\mathrm{p}: 0.175\end{array}$ & $\begin{array}{l}\mathrm{r}: 0.110 \\
\mathrm{p}: 0.506\end{array}$ & $\begin{array}{l}\mathrm{r}: 0.193 \\
\mathrm{p}: 0.239\end{array}$ & $\begin{array}{l}\mathrm{r}:-0.152 \\
\mathrm{p}: 0.356\end{array}$ \\
\hline BASFI & $\begin{array}{l}\mathrm{r}: 0.042 \\
\mathrm{p}: 0.798\end{array}$ & $\begin{array}{l}\mathrm{r}:-0.009 \\
\mathrm{p}: 0.957\end{array}$ & $\begin{array}{l}\mathrm{r}: 0.166 \\
\mathrm{p}: 0.313\end{array}$ & $\begin{array}{l}\mathrm{r}: 0.121 \\
\mathrm{p}: 0.463\end{array}$ & $\begin{array}{l}\mathrm{r}:-0.036 \\
\mathrm{p}: 0.826\end{array}$ & $\begin{array}{l}\mathrm{r}: 0.040 \\
\mathrm{p}: 0.810\end{array}$ & $\begin{array}{c}\mathrm{r}:-0.035 \\
\mathrm{p}: 0.831\end{array}$ \\
\hline BASDAI & $\begin{array}{l}\mathrm{r}:-0.156 \\
\mathrm{p}: 0.348\end{array}$ & $\begin{array}{l}\mathrm{r}:-0.241 \\
\mathrm{p}: 0.144\end{array}$ & $\begin{array}{l}\mathrm{r}: 0.104 \\
\mathrm{p}: 0.533\end{array}$ & $\begin{array}{l}\mathrm{r}: 0.050 \\
\mathrm{p}: 0.766\end{array}$ & $\begin{array}{c}\mathrm{r}:-0.094 \\
\mathrm{p}: 0.575\end{array}$ & $\begin{array}{l}\mathrm{r}:-0.126 \\
\mathrm{p}: 0.450\end{array}$ & $\begin{array}{l}\mathrm{r}: 0.123 \\
\mathrm{p}: 0.461\end{array}$ \\
\hline BASMI & $\begin{array}{l}\mathrm{r}:-0.178 \\
\mathrm{p}: 0.285\end{array}$ & $\begin{array}{l}\mathrm{r}:-0.118 \\
\mathrm{p}: 0.479\end{array}$ & $\begin{array}{l}\mathrm{r}: 0.047 \\
\mathrm{p}: 0.779\end{array}$ & $\begin{array}{l}\mathrm{r}:-0.020 \\
\mathrm{p}: 0.904\end{array}$ & $\begin{array}{l}\mathrm{r}:-0.075 \\
\mathrm{p}: 0.656\end{array}$ & $\begin{array}{l}\mathrm{r}:-0.114 \\
\mathrm{p}: 0.495\end{array}$ & $\begin{array}{l}\mathrm{r}: 0.189 \\
\mathrm{p}: 0.257\end{array}$ \\
\hline
\end{tabular}

Measuring the subjective components of sexual function is becoming increasingly important in clinical research and practice. ${ }^{[26]}$ In research and practice-based settings, patient self-administered questionnaires are valuable tools for assessing sexual function. ${ }^{[27]}$ To our knowledge, there have been four studies that investigated the sexual functions of male patients with AS with a validated scoring scale in the literature..$^{[9,12-14]}$ Different validated scales [the IIEF, the Golombok Rust Inventory of Sexual Satisfaction (GRISS), and the

Table 5. The relationship between quality of life, the beck depression inventory, and the International Index of Erectile Function scores in the male patients with ankylosing spondylitis

\begin{tabular}{|c|c|c|c|c|c|c|c|}
\hline & $\begin{array}{l}\text { Erectile } \\
\text { function }\end{array}$ & $\begin{array}{c}\text { Orgasmic } \\
\text { function }\end{array}$ & $\begin{array}{l}\text { Sexual } \\
\text { drive }\end{array}$ & $\begin{array}{l}\text { Intercourse } \\
\text { satisfaction }\end{array}$ & $\begin{array}{c}\text { Overall } \\
\text { satisfaction }\end{array}$ & $\begin{array}{l}\text { Total } \\
\text { IIEF }\end{array}$ & $\begin{array}{l}\text { Level of } \\
\text { ED }\end{array}$ \\
\hline ASQoL & $\begin{array}{c}\mathrm{r}:-0.261 \\
\mathrm{p}: 0.130\end{array}$ & $\begin{array}{l}\mathrm{r}:-0.161 \\
\mathrm{p}: 0.356\end{array}$ & $\begin{array}{c}\mathrm{r}:-0.099 \\
\mathrm{p}: 0.570\end{array}$ & $\begin{array}{l}\mathrm{r}:-0.091 \\
\mathrm{p}: 0.603\end{array}$ & $\begin{array}{l}\mathrm{r}:-0.384 \\
\mathrm{p}: 0.023\end{array}$ & $\begin{array}{c}\mathrm{r}:-0.266 \\
\mathrm{p}: 0.122\end{array}$ & $\begin{array}{l}\mathrm{r}: 0.210 \\
\mathrm{p}: 0.225\end{array}$ \\
\hline Beck depression inventory & $\begin{array}{l}\mathrm{r}:-0.356 \\
\mathrm{p}: 0.026\end{array}$ & $\begin{array}{l}\mathrm{r}:-0.313 \\
\mathrm{p}: 0.053\end{array}$ & $\begin{array}{l}\mathrm{r}:-0.311 \\
\mathrm{p}: 0.054\end{array}$ & $\begin{array}{l}\text { r: }-0.270 \\
\text { p:0.097 }\end{array}$ & $\begin{array}{c}\mathrm{r}:-0.392 \\
\mathrm{p}: 0.014\end{array}$ & $\begin{array}{c}\mathrm{r}:-0.409 \\
\mathrm{p}: 0.010\end{array}$ & $\begin{array}{l}\mathrm{r}: 0.389 \\
\mathrm{p}: 0.014\end{array}$ \\
\hline $\begin{array}{l}\text { Short Form } 36 \\
\text { Physical function }\end{array}$ & $\begin{array}{l}\mathrm{r}: 0.215 \\
\mathrm{p}: 0.188\end{array}$ & $\begin{array}{l}\mathrm{r}: 0.132 \\
\mathrm{p}: 0.422\end{array}$ & $\begin{array}{l}\mathrm{r}:-0.034 \\
\mathrm{p}: 0.837\end{array}$ & $\begin{array}{l}\mathrm{r}:-0.139 \\
\mathrm{p}: 0.400\end{array}$ & $\begin{array}{l}\mathrm{r}: 0.133 \\
\mathrm{p}: 0.418\end{array}$ & $\begin{array}{l}\mathrm{r}: 0.140 \\
\mathrm{p}: 0.395\end{array}$ & $\begin{array}{l}\mathrm{r}:-0.201 \\
\mathrm{p}: 0.219\end{array}$ \\
\hline Role emotional & $\begin{array}{l}\mathrm{r}: 0.193 \\
\mathrm{p}: 0.261\end{array}$ & $\begin{array}{l}\mathrm{r}: 0.280 \\
\mathrm{p}: 0.098\end{array}$ & $\begin{array}{l}\mathrm{r}: 0.105 \\
\mathrm{p}: 0.542\end{array}$ & $\begin{array}{l}\mathrm{r}: 0.192 \\
\mathrm{p}: 0.261\end{array}$ & $\begin{array}{l}\mathrm{r}: 0.161 \\
\mathrm{p}: 0.347\end{array}$ & $\begin{array}{l}\mathrm{r}: 0.246 \\
\mathrm{p}: 0.149\end{array}$ & $\begin{array}{l}\mathrm{r}:-0.089 \\
\mathrm{p}: 0.606\end{array}$ \\
\hline Pain & $\begin{array}{l}\mathrm{r}:-0.104 \\
\mathrm{p}: 0.530\end{array}$ & $\begin{array}{l}\mathrm{r}: 0.037 \\
\mathrm{p}: 0.824\end{array}$ & $\begin{array}{c}\mathrm{r}:-0.226 \\
\mathrm{p}: 0.166\end{array}$ & $\begin{array}{c}\mathrm{r}:-0.403 \\
\mathrm{p}: 0.011\end{array}$ & $\begin{array}{c}\mathrm{r}:-0.046 \\
\mathrm{p}: 0.781\end{array}$ & $\begin{array}{l}\mathrm{r}:-0.140 \\
\mathrm{p}: 0.397\end{array}$ & $\begin{array}{l}\mathrm{r}: 0.215 \\
\mathrm{p}: 0.188\end{array}$ \\
\hline General health & $\begin{array}{l}\mathrm{r}: 0.208 \\
\mathrm{p}: 0.203\end{array}$ & $\begin{array}{l}\mathrm{r}: 0.248 \\
\mathrm{p}: 0.128\end{array}$ & $\begin{array}{l}\mathrm{r}:-0.067 \\
\mathrm{p}: 0.686\end{array}$ & $\begin{array}{l}\mathrm{r}:-0.128 \\
\mathrm{p}: 0.438\end{array}$ & $\begin{array}{l}\mathrm{r}: 0.138 \\
\mathrm{p}: 0.401\end{array}$ & $\begin{array}{l}\mathrm{r}: 0.163 \\
\mathrm{p}: 0.321\end{array}$ & $\begin{array}{l}\mathrm{r}:-0.154 \\
\mathrm{p}: 0.349\end{array}$ \\
\hline Vitality & $\begin{array}{l}\mathrm{r}: 0.090 \\
\mathrm{p}: 0.584\end{array}$ & $\begin{array}{l}\mathrm{r}: 0.293 \\
\mathrm{p}: 0.070\end{array}$ & $\begin{array}{l}\mathrm{r}: 0.157 \\
\mathrm{p}: 0.338\end{array}$ & $\begin{array}{c}\mathrm{r}:-0.042 \\
\mathrm{p}: 0.798\end{array}$ & $\begin{array}{l}\mathrm{r}: 0.313 \\
\mathrm{p}: 0.052\end{array}$ & $\begin{array}{l}\mathrm{r}: 0.179 \\
\mathrm{p}: 0.276\end{array}$ & $\begin{array}{l}\mathrm{r}:-0.026 \\
\mathrm{p}: 0.874\end{array}$ \\
\hline Social function & $\begin{array}{l}\mathrm{r}: 0.254 \\
\mathrm{p}: 0.141\end{array}$ & $\begin{array}{l}\mathrm{r}: 0.338 \\
\mathrm{p}: 0.047\end{array}$ & $\begin{array}{l}\mathrm{r}: 0.206 \\
\mathrm{p}: 0.234\end{array}$ & $\begin{array}{l}\mathrm{r}: 0.044 \\
\mathrm{p}: 0.800\end{array}$ & $\begin{array}{l}\mathrm{r}: 0.197 \\
\mathrm{p}: 0.257\end{array}$ & $\begin{array}{l}\mathrm{r}: 0.287 \\
\mathrm{p}: 0.094\end{array}$ & $\begin{array}{l}\mathrm{r}:-0.124 \\
\mathrm{p}: 0.477\end{array}$ \\
\hline Role physical & $\begin{array}{l}\mathrm{r}: 0.169 \\
\mathrm{p}: 0.318\end{array}$ & $\begin{array}{l}\mathrm{r}: 0.120 \\
\mathrm{p}: 0.481\end{array}$ & $\begin{array}{c}\mathrm{r}:-0.045 \\
\mathrm{p}: 0.791\end{array}$ & $\begin{array}{l}\mathrm{r}:-0.142 \\
\mathrm{p}: 0.403\end{array}$ & $\begin{array}{l}\mathrm{r}: 0.080 \\
\mathrm{p}: 0.640\end{array}$ & $\begin{array}{l}\mathrm{r}: 0.081 \\
\mathrm{p}: 0.633\end{array}$ & $\begin{array}{c}\mathrm{r}:-0.071 \\
\mathrm{p}: 0.674\end{array}$ \\
\hline Mental health & $\begin{array}{l}\mathrm{r}: 0.068 \\
\mathrm{p}: 0.684\end{array}$ & $\begin{array}{l}\mathrm{r}: 0.144 \\
\mathrm{p}: 0.387\end{array}$ & $\begin{array}{l}\mathrm{r}: 0.109 \\
\mathrm{p}: 0.516\end{array}$ & $\begin{array}{l}\mathrm{r}: 0.039 \\
\mathrm{p}: 0.817\end{array}$ & $\begin{array}{l}\mathrm{r}: 0.215 \\
\mathrm{p}: 0.196\end{array}$ & $\begin{array}{l}\mathrm{r}: 0.136 \\
\mathrm{p}: 0.417\end{array}$ & $\begin{array}{l}\mathrm{r}:-0.035 \\
\mathrm{p}: 0.836\end{array}$ \\
\hline
\end{tabular}


Brief Male Sexual Function Inventory (BMSFI)] were used in these studies, and each of these instruments includes different domains of sexual life. The IIEF measures erectile function, orgasmic function, sexual drive, and sexual satisfaction ${ }^{[26]}$ and has become the reference standard for assessing ED. ${ }^{[27]}$ This scale is designed specifically for the assessment of sexual function in clinical research or practice. The relative brevity and ease of use are some of its advantages. ${ }^{[28]}$ The GRISS, a self-reporting questionnaire, was designed to assess the quality of a heterosexual relationship and individual sexual functioning. ${ }^{[29,30]}$ The BMSFI was developed as a validated way to characterize sexual function by clinicians and researchers. ${ }^{[31]}$ Dinçer et al. ${ }^{[13]}$ used the BMSFI scale and found that all of its domains, except for the ejaculation domain, were significantly lower in male patients with AS compared with healthy controls. Özkorumak et al. ${ }^{[14]}$ used the GRISS scale and evaluated 43 male patients with AS and found that the frequency of sexual dysfunction was significantly higher in these patients than for the healthy controls. The IIEF scoring scale was used in two previous studies. ${ }^{[9,12]}$ Prrildar et al. ${ }^{[9]}$ reported that all domains of the IIEF, except for sexual drive, were significantly lower in male patients with AS than in the healthy control group, and Bal et al. ${ }^{[12]}$ could not find any significant differences in terms of the IIEF, except for the sexual drive domain. Three of these studies concluded that sexual function was significantly affected by AS. ${ }^{[9,13,14]}$ In our study, we used the IIEF scale, and our results were in line with the study done by Bal et al. ${ }^{[12]}$ We found no significant difference in sexual functions between the male patients with AS and the healthy controls, but the sexual drive domain of the IIEF was slightly lower in those with AS. However, this difference was not at a significant level.

Thereasonsfor sexualdysfunction are multifactorial. Symptoms of depression and anxiety are important comorbidities in chronic diseases, and depression is also one of the reported factors for sexual dysfunction in patients with $\mathrm{AS}^{[8]}$ When we examined previous studies, the relationship between depression and sexual function was evaluated in three of them..$^{[9,13,14]}$ The healthy controls had significantly lower BDI scores than patients with AS in these studies. Prrildar et al. ${ }^{[9]}$ found that $38 \%$ of their AS patients were depressed according to the BDI, and patients with higher BDI scores had lower erectile function. Dinçer et al. ${ }^{[13]}$ found a significant association between the BMSFI and BDI scores in both patients with AS and the healthy control group. Özkorumak et al. ${ }^{[14]}$ evaluated patients' anxiety level using the Beck Anxiety Inventory (BAI) and their depression level with the BDI and found that the patients with AS had significantly higher rates of depression and anxiety levels than the controls in their study. In addition, there was a statistically significant relationship between the total GRISS and the BDI and BAI scores. Bal et al. ${ }^{[12]}$ did not evaluate the depression level in their study population. In our study design, we excluded patients who had been diagnosed with depression or other affected disorders. There was no significant difference between the male patients with AS and the healthy controls according to the BDI scores. The insignificance of the depression scores between the AS patients and the controls could be a reason for the similar sexual functions that were identified. Our results also indicated significant correlations between the BDI and the total IIEF, erectile function, overall satisfaction, and level of ED in the male patients with AS.

It is understood that there is an association between disease activity and sexual functions. Pirıldar et al. ${ }^{[9]}$ did not evaluate the BASDAI in their study; however, they investigated the correlation between laboratory and clinical parameters and ED and found no relationship between these parameters, except for the duration of morning stiffness. Dinçer et al. ${ }^{[13]}$ also could not find any correlation between morning stiffness, the BASDAI, and sexual functions. In contrast, Özkorumak et al. ${ }^{[14]}$ found a significant relationship between the BASDAI and the total GRISS score. Bal et al. ${ }^{[12]}$ found that the duration of morning stiffness and the BASDAI were negatively correlated with sexual drive and the overall satisfaction domains of the IIEF. In our study, we evaluated disease activity with the BASDAI and could not find any association between it and the domains of the IIEF.

Functional activity is also considered to have a negative correlation with sexual function. Three of the previous studies investigated the relationship between the BASFI and sexual functions. ${ }^{[12-14]}$ While two of them could not find any correlation, ${ }^{[12,13]}$ Özkorumak et al. ${ }^{[14]}$ reported a significant but modest correlation. There was no significant correlation between the BASFI and the IIEF in our study.

Bal et al. ${ }^{[12]}$ found a BASMI score of $3.9 \pm 2.4$ and could find no correlation between the IIEF and the BASMI. Dinçer et al. ${ }^{[13]}$ found a BASMI score of 2.6 \pm 2.1 and discovered a significant correlation between the BASMI and the total BMSFI. In addition, the modified Schober's test results and intermalleolar distance were 
correlated with the BMSFI in their study. Özkorumak et al. ${ }^{[14]}$ found a BASMI score of $2.67 \pm 2.40$ and reported a significant correlation between it and the total GRISS. In the present study, the BASMI score was $3.28 \pm 1.88$, and there was a correlation between the BASMI and the IIEF.

Sexual function is recognized as a component of QoL. ${ }^{[26]}$ In the previous studies which used a validated questionnaire to evaluate sexual functions in patients with AS, only Bal et al. ${ }^{[12]}$ evaluated QoL with the SF-36. They found a negative correlation between the social function item of the SF-36 and sexual drive along with the overall satisfaction domains of the IIEF. In this study, we evaluated the SF-36 as a generic QoL measurement and disease-specific, health-related QoL with the ASQoL. We did not compare the QoL of the male AS patients with the healthy controls. However, we found significant correlations between the pain subscale of the SF-36 and the intercourse satisfaction domain of the IIEF and between the social function subscale of the SF-36 and the orgasmic function. Additionally, the ASQoL was found to be correlated with the overall satisfaction domain of the IIEF.

No significant correlation was found between sexual functions and CRP levels and ESR in either the previous studies ${ }^{[9,12,13]}$ or our study.

There were several limitations in the present study. There is a strong relationship between ED and both physical and psychological risk factors. ${ }^{[28]}$ Multiple factors which could contribute to the development of ED, such as smoking status, educational level, and alcohol consumption, were not addressed. It has been reported that educating patients about their disease could decrease negative feelings, enhance the ability to cope with the disease, and improve the QoL. ${ }^{[32]}$ We did not include subjects with a history of comorbidities like diabetes, dyslipidemia, or hypogonadism or those who were under medications such as antidepressants.

The rational explanation for the similar level of sexual functions between the male patients with AS and the healthy controls might be summarized as the following: (i) the patient sample included in the study was taken from the Rheumatology Outpatient Clinic of a tertiary care center, and all of the patients were in regular follow-up care and had significant knowledge about the disease, (ii) most of the patients' disease activity was low, (iii) all the patients used to fulfill selfassessment questionnaires, (iv) there was no difference in depressive mood between the patients and controls.
In conclusion, sexual dysfunction is common in male patients with AS. However, we could find no statistically significant differences between these patients and the healthy male control group in terms of sexual functions. Male sexual issues in patients with AS seem to be associated with an unfavorable psychological status, but further longitudinal studies are necessary to clarify the exact relationship between sexual functions and psychological status.

\section{Acknowledgements}

We are grateful to Ömer Uysal, $\mathrm{PhD}$ for his patience and his contributions to the statistical analyses.

\section{Declaration of conflicting interests}

The authors declared no conflicts of interest with respect to the authorship and/or publication of this article.

\section{Funding}

The authors received no financial support for the research and/or authorship of this article.

\section{REFERENCES}

1. NIH Consensus Conference. Impotence. NIH Consensus Development Panel on Impotence. JAMA 1993;270:83-90.

2. Wiltink J, Subic-Wrana C, Tuin I, Weidner W, Beutel ME. Repressive coping style and its relation to psychosocial distress in males with erectile dysfunction. J Sex Med 2010;7:2120-9.

3. Cakar E, Dincer U, Kiralp MZ, Taskaynatan MA, Yasar E, Bayman EO, et al. Sexual problems in male ankylosing spondylitis patients: relationship with functionality, disease activity, quality of life, and emotional status. Clin Rheumatol 2007;26:1607-13.

4. Østensen M. New insights into sexual functioning and fertility in rheumatic diseases. Best Pract Res Clin Rheumatol 2004;18:219-32.

5. Gran JT, Husby G. The epidemiology of ankylosing spondylitis. Semin Arthritis Rheum 1993;22:319-34.

6. Gran JT, Skomsvoll JF. The outcome of ankylosing spondylitis: a study of 100 patients. Br J Rheumatol 1997;36:766-71.

7. Carette S, Graham D, Little H, Rubenstein J, Rosen P. The natural disease course of ankylosing spondylitis. Arthritis Rheum 1983;26:186-90.

8. Tristano AG. The impact of rheumatic diseases on sexual function. Rheumatol Int 2009;29:853-60.

9. Pirildar T, Müezzinoğlu T, Pirildar S. Sexual function in ankylosing spondylitis: a study of 65 men. J Urol 2004;171:1598-600.

10. Akkus E, Kadioglu A, Esen A, Doran S, Ergen A, Anafarta K, et al. Prevalence and correlates of erectile dysfunction in Turkey: a population-based study. Eur Urol 2002;41:298-304. 
11. Healey EL, Haywood KL, Jordan KP, Garratt AM, Ryan S, Packham JC. Ankylosing spondylitis and its impact on sexual relationships. Rheumatology (Oxford) 2009;48:1378-81.

12. Bal S, Bal K, Turan Y, Deniz G, Gürgan A, Berkit IK, et al. Sexual functions in ankylosing spondylitis. Rheumatol Int 2011;31:889-94.

13. Dincer U, Cakar E, Kiralp MZ, Dursun H. Assessment of sexual dysfunction in male patients with Ankylosing Spondylitis. Rheumatol Int 2007;27:561-6.

14. Ozkorumak E, Karkucak M, Civil F, Tiryaki A, Ozden G. Sexual function in male patients with ankylosing spondylitis. Int J Impot Res 2011;23:262-7.

15. van der Linden S, Valkenburg HA, Cats A. Evaluation of diagnostic criteria for ankylosing spondylitis. A proposal for modification of the New York criteria. Arthritis Rheum 1984;27:361-8.

16. Jenkinson TR, Mallorie PA, Whitelock HC, Kennedy LG, Garrett SL, Calin A. Defining spinal mobility in ankylosing spondylitis (AS). The Bath AS Metrology Index. J Rheumatol 1994;21:1694-8.

17. Calin A, Garrett S, Whitelock H, Kennedy LG, O’Hea J, Mallorie P, et al. A new approach to defining functional ability in ankylosing spondylitis: the development of the Bath Ankylosing Spondylitis Functional Index. J Rheumatol 1994;21:2281-5.

18. Karatepe AG, Akkoc Y, Akar S, Kirazli Y, Akkoc N. The Turkish versions of the Bath Ankylosing Spondylitis and Dougados Functional Indices: reliability and validity. Rheumatol Int 2005;25:612-8.

19. Garrett S, Jenkinson T, Kennedy LG, Whitelock H, Gaisford $\mathrm{P}$, Calin A. A new approach to defining disease status in ankylosing spondylitis: the Bath Ankylosing Spondylitis Disease Activity Index. J Rheumatol 1994;21:2286-91.

20. Akkoc Y, Karatepe AG, Akar S, Kirazli Y, Akkoc N. A Turkish version of the Bath Ankylosing Spondylitis Disease Activity Index: reliability and validity. Rheumatol Int 2005;25:280-4.

21. Ware JE Jr, Sherbourne CD. The MOS 36-item short-form health survey (SF-36). I. Conceptual framework and item selection. Med Care 1992;30:473-83.
22. Doward LC, Spoorenberg A, Cook SA, Whalley D, Helliwell PS, Kay LJ, et al. Development of the ASQoL: a quality of life instrument specific to ankylosing spondylitis. Ann Rheum Dis 2003;62:20-6.

23. Rosen RC, Riley A, Wagner G, Osterloh IH, Kirkpatrick J, Mishra A. The international index of erectile function (IIEF): a multidimensional scale for assessment of erectile dysfunction. Urology 1997;49:822-30.

24. Tokatli Z, Akand M, Yaman O, Gulpinar O, Anafarta K. Comparison of international index of erectile function with nocturnal penile tumescence and rigidity testing in evaluation of erectile dysfunction. Int J Impot Res 2006;18:186-9.

25. Beck AT, Ward CH, Mendelson M, Mock J, Erbaugh J. An inventory for measuring depression. Arch Gen Psychiatry 1961;4:561-71.

26. Daker-White G. Reliable and valid self-report outcome measures in sexual (dys)function: a systematic review. Arch Sex Behav 2002;31:197-209.

27. Rosen RC, Catania JA, Althof SE, Pollack LM, O'Leary M, Seftel AD, et al. Development and validation of four-item version of Male Sexual Health Questionnaire to assess ejaculatory dysfunction. Urology 2007;69:805-9.

28. Rosen RC. Evaluation of the patient with erectile dysfunction: history, questionnaires, and physical examination. Endocrine 2004;23:107-11.

29. Rizvi SJ, Yeung NW, Kennedy SH. Instruments to measure sexual dysfunction in community and psychiatric populations. J Psychosom Res 2011;70:99-109.

30. Smith KB, Pukall CF, Tripp DA, Nickel JC. Sexual and relationship functioning in men with chronic prostatitis/ chronic pelvic pain syndrome and their partners. Arch Sex Behav 2007;36:301-11.

31. O'Leary MP, Rhodes T, Girman CJ, Jacobson DJ, Roberts RO, Lieber MM, et al. Distribution of the Brief Male Sexual Inventory in community men. Int J Impot Res 2003;15:185-91.

32. Ozgül A, Peker F, Taskaynatan MA, Tan AK, Dinçer K, Kalyon TA. Effect of ankylosing spondylitis on healthrelated quality of life and different aspects of social life in young patients. Clin Rheumatol 2006;25:168-74. 